\title{
PENERAPAN METODE PROBLEM POSING UNTUK MENINGKATKAN AKTIVITAS DAN HASIL BELAJAR SISWA MATA PELAJARAN IPA KELAS IV SD 165727 TEBING TINGGI
}

\author{
Serlitan Panjaitan \\ Surel: serlitan.pjt @gmail.com
}

\begin{abstract}
This aim of this research is to improve learning result on science subject through problem posing method. This classroom action research conducted by 2 cycles of the four phases: planning, implementation, observation, reflection. The subjects were students from grade IV, SD Negeri 165727 Tebing Tinggi which amounted to 32 students. This study used a qualitative descriptive analysis technique. The results showed that the method of the problem posing in science subject can improve student learning result characterized by increased mastery learning students, namely pre-cycle (75\%), the first cycle (81,25\%), cycle II (93,7 \%) and complete learn the clasical equal to $93,75 \%$.
\end{abstract}

Keyword: Problem Posing, Science, Learning

\begin{abstract}
ABSTRAK
Penelitian ini bertujuan untuk meningkatkan hasil belajar siswa mata pelajaran IPA melalui metode problem posing. Penelitian tindakan kelas ini dilaksanakan sebanyak 2 siklus dengan empat tahapan yaitu : perencanaan, pelaksanaan, observasi, refleksi. Subjek penelitian ini adalah siswa kelas IV SD Negeri 165727 Tebing Tinggi sebanyak 32 siswa. Penelitian ini menggunakan teknik analisis dekriptif kualitatif. Hasil penelitian menunjukkan bahwa penggunaan metode problem posing mata pelajaran IPA dapat meningkatkan hasil belajar siswa yang ditandai dengan peningkatan ketuntasan belajar siswa, yaitu pra siklus $(75 \%)$, siklus I $(81,25$ $\%)$, siklus II $(93,7 \%)$ dan dinyatakan berhasil secara klasikal 93,75\%.
\end{abstract}

Kata Kunci: Problem Posing, IPA, Belajar

\section{PENDAHULUAN}

Belajar adalah suatu proses usaha yang dilakukan individu untuk memperoleh suatu perubahan tingkah laku yang baru secara keseluruhan, sebagai hasil pengamatan individu itu sendiri dalam interaksi dengan lingkungan. Pembelajaran merupakan proses yang berfungsi membimbing siswa di dalam kehidupan yakni membimbing mengembangkan diri sesuai dengan tugas perkembangan yang harus dijalankan oleh siswa tersebut. Proses belajar mengajar adalah salah satunya ditandai dengan adanya aktivitas siswa. IPA adalah pengetahuan manusia tentang alam

SD Negeri 165727 Tebing Tinggi 
yang diperoleh alam dengan cara yang terkontrol (Muslichah, 2006). Pembelajaran IPA merupakan proses membelajarkan subjek didik dalam mempelajari peristiwa yang terjadi di alam ini melalui serangkaian proses ilmiah sehingga tercapai tujuan pembelajaran yang sudah ditetapkan. Selain itu, merupakan mata pelajaran yang sudah diperkenalkan kepada siswa sejak di bangku taman kanakkanak. Permasalahan IPA dikatakan penting bagi siswa karena berhubungan dengan lingkungan alam sekitar.

IPA adalah pengetahuan manusia tentang alam yang diperoleh alam dengan cara yang terkontrol (Dimyati dan Mudjiono, 2006). Pembelajaran IPA harus menekan-kan pada penguasaan kompetensi melalui se-rangkaian proses ilmiah dan pemecahan masalah sehingga siswa lebih mudah memahami konsep pembelajaran. Selama ini pada umumnya model pembelajaran yang dikembangkan di sekolah cenderung dilakukan secara individu dan ceramah sebagian besar siswa sulit memahami materi pelajaran.

Kenyataannya di lapangan, hasil belajar siswa kelas IV SD Negeri 165727 Tebing Tinggi pada kondisi awal masih dikategorikan kurang baik. Hal ini dapat dilihat dari nilai evaluasi ulangan harian pra siklus yang rendah yaitu dengan ratarata nilai 67 dengan jumlah siswa yang lulus KKM 24 siswa (75\%). Nilai KKM yang ditetapkan adalah 70.

Untuk membuat siswa belajar maka pendidik harus merencanakan dan mendesain suatu pembelajaran antara lain materi, tujuan pembelajaran, strategi maupun metode, sehingga pembelajaran tersebut dapat mencapai tujun pembelajaran secara efektif dan efisien.

Selain itu, problem posing diartikan sebagai pembentukan soal berdasarkan konteks, cerita, informasi, atau gambar yang diketahui (Mahmudi, 2008: 4). Istilah lain yang berpadanan dengan problem posing adalah pengajuan masalah. Sebagai pendekatan, pengajuan masalah berkaitan dengan alat yang perlu dimiliki guru sehingga mampu mendorong dan melatih siswa dalam merumuskan pertanyaan matematik dan kemudian menentukan penyelesaiannya. Pendekatan ini lebih ditekankan pada kegiatan membentuk soal yang dilakukan oleh siswa sendiri. Hal ini memberi kesempatan yang luas kepada siswa untuk mengkonstruk pengetahuan sesuai dengan perkembangan pengetahuan berfikirnya (Kusumah, 2004: 8).

Berdasarkan permasalahan tersebut maka alternatif pendekatan pembelajaran yang tepat pada mata pelajaran IPA yaitu dengan metode problem posing. Pembelajaran dengan 
pendekatan problem posing memberi kesempatan kepada peserta didik berpartisipasi lebih aktif untuk meluangkan ide-ide atau masalahmasalah yang dihadapi melalui pengajuan soal yang nantinya akan ditukarkan dengan kelompok lain untuk dijawab yang nantinya akan dibahas bersama.

Berdasarkan uraian pada latar belakang masalah, maka dapat dirumuskan permasalahan sebagai berikut: "Apakah dengan menggunakan pembelajaran metode problem posing meningkatkan hasil belajar IPA siswa kelas IV SD Negeri 165727 kota Tebing Tinggi Tahun pelajaran 2015/2016?"

Tujuan dari penelitian ini adalah untuk meningkatkan aktivitas dan hasil belajar siswa kelas IV SD Negeri 165727 Tebing Tinggi tahun pembelajaran 2013/2014 melalui metode problem posing pada mata pelajaran IPA.

\section{METODE PENELITIAN}

Penelitian ini dilaksanakan pada bulan September sampai dengan bulan Februari 2016 pada semester genap tahun ajaran 2015/2016. Penelitian ini dilaksanakan dalam 2 siklus, yaitu siklus pertama selama 2 kali pertemuan dan siklus kedua selama 2 kali pertemuan. Peneliti mengambil lokasi penelitian tindakan kelas di SD Negeri 165727 Tebing Tinggi. Subyek penelitian adalah siswa kelas IV SD Negeri 165727 Tebing Tinggi dengan jumlah siswa sebanyak 32 orang dengan 15 orang laki-laki dan 17 orang perempuan. Sumber data yang digunakan adalah siswa dan teman sejawat.

Pada Penelitian tindakan kelas data yang dikumpulkan dapat berbentuk kuantitatif maupun kualitatif. Data kuantitatif yang berupa nilai dianalisis dengan menggunakan analisis deskriptif komparatif yaiu membandingkan nilai tes kondisi awal, nilai tes setelah siklus I dan II yaitu nilai dari hasil ulangan harian siswa kelas IV SD Negeri 165727 pada siklus I dan II. Metode penelitian yang digunakan dalam penelitian ini adalah Classroom Action Research atau penelitian tindakan kelas.

Model penelitian tindakan kelas yang digunakan peneliti adalah sistem spiral refleksi diri yang dikembangkan oleh Kemmis dan Taggart yang dimulai dengan perencanaan, tindakan, pengamatan, dan refleksi. Masing-masing siklus terdiri dari dua kali pertemuan yaitu sebagai berikut:

\section{Perencanaan}

Pada tahapan ini dilakukan berbagai persiapan dan perencanaan tindakan yang meliputi: menyusun skenario pembelajaran berupa Rencana Pelaksaan Pembelajaran, mempersiapkan media pembelajaran dan alat observasi, dan membuat 
instrumen untuk evaluasi yang berupa soal tes tertulis. Selain mempersiapkan hal-hal tersebut, untuk dapat melaksanakan penelitian ini dengan tujuan yang jelas peneliti juga perlu menetapkan indikator ketercapaian dalam penerapan metode problem posing.

2. Pelaksanaan

\section{a. Siklus I}

Guru melakukan pembelajaran di dalam kelas dengan menggunakan panduan perencanaan yang telah dibuat. Siklus I dilakukan pada tanggal 5 Februari 2016. Penerapan metode Penggunaan model problem posing diharapkan dapat memancing siswa untuk menemukan pengetahuan yang bukan dilibatkan dari ketidaksengajaan melainkan melalui upaya mereka untuk mencari hubungan-hubungan tersebut. Pada akhirnya, penemuan pertanyaan serta jawaban yang dihasilkan terhadapnya dapat menyebabkan perubahan dan ketergantungan pada penguatan luar pada rasa puas akibat keberhasilan menemukan sendiri, baik berupa pertanyaan atau masalah maupun jawaban atas permasalah yang diajukan.

Kompetensi dasar pada siklus ini yaitu membuat gambar / denah berdasarkan penjelasan yang didengar. Pada saat kegiatan pembelajaran berlangsung guru sebagai peneliti dibantu oleh para observer lainnya untuk melakukan pengamatan, mendokumentasi kegiatan, selain itu peneliti bertindak sebagai fasilitator, motivator dan sekaligus sebagai pengamat.

\section{b. Siklus II}

Guru melakukan pembelajaran di dalam kelas dengan menggunakan panduan perencanaan yang telah dibuat. Siklus II dilakukan pada tanggal 19 Februari 2016. Siswa mengajukan pertanyaan sendiri mengenai materi yang dipelajari. Pada akhirnya, penemuan pertanyaan serta jawaban yang dihasilkan terhadapnya dapat menyebabkan perubahan dan ketergantungan pada penguatan luar pada rasa puas akibat keberhasilan menemukan sendiri, baik berupa pertanyaan atau masalah maupun jawaban atas permasalah yang diajukan.

Kompetensi dasar pada siklus ini adalah melengkapi percakapan yang belum selesai dengan memperhatikan penggunaan ejaan (tanda titik dua dan tanda petik). Pada saat kegiatan pembelajaran berlangsung guru sebagai peneliti dibantu oleh para observer lainnya untuk melakukan pengamatan, mendokumentasi kegiatan, selain itu peneliti bertindak sebagai fasilitator, motivator dan sekaligus sebagai pengamat. 
3. Observasi/Pengamatan

Observasi digunakan untuk pengumpulan data aktivitas belajar bahasa Indonesia siswa dalam pembelajaran. Pengumpulan data melalui observasi dilakukan secara partisipatif, yang berarti pengamat ikut serta dalam kegiatan belajar mengajar yang dilakukan oleh subjek yang diamati (Sanjaya, 2010: 92). Pengamatan dilakukan peneliti sendiri dan dibantu oleh pengamat dan mencatat proses penerapan teknik pengajaran kolaborasi.

\section{d. Refleksi}

Peneliti mengkaji, melihat dan mempertimbangkan hasil atau dampak dari tindakan yang dilakukan berdasarkan lembar pengamatan yang diisi oleh pengamat. Kegiatan pada tahap refleksi meliputi kegiatan menganalisis, memahami dan membuat kesimpulan berdasarkan hasil observasi setiap siklus. menemukan kelebihan dan kelemahan tindakan perbaikan pembelajaran.

Hasil analisis data yang dilaksanakan pada tahap ini akan dipergunakan untuk menemukan kelebihan dan kelemahan diri dalam merancang dan melakukan tindakan sebagai acuan. Instrumen yang digunakan dalam penelitian ini adalah pedoman observasi, test hasil belajar, dan wawancara. Data aktivitas belajar dan kendala yang dihadapi selama proses pembelajaran dikumpulkan melalui observasi (lembar observasi terlampir). Hal-hal yang akan diobservasi adalah kegiatan lisan, kegiatan metrik, kegiatan emosional. Data hasil observasi, dan data hasil wawancara yang jenis datanya berupa pernyataan-pernyataan, dianalisis dengan menggunakan teknik analisis statistik deskriptif.

Metode pengumpulan data penelitian ini adalah tertulis dan observasi. Penelitian ini dikatakan berhasil apabila siswa telah memperoleh nilai ketuntasan secara klasikal minimal $85 \%$ dari jumlah siswa dengan rumus sebagai berikut:

Persentase Ketuntasan klasikal $=$

Jumlah siswa yang tuntas $\times 100 \%$

Jumlah siswa yang mengikuti tes

\section{HASIL DAN PEMBAHASAN}

Peneliti melaksanakan tes awal yang bertujuan untuk mengetahui kemampuan awal siswa pada materi penarikan kesimpulan logika matematika dan untuk dijadikan alat dalam pembentukan kelompok yang bersifat heterogen. Dari hasil analisis tes awal tersebut peneliti memeriksa bahwa dari 32 orang siswa yang mengikuti tes tersebut, hanya terdapat 24 orang siswa yang dapat menyelesaikan soal dengan benar. Hal ini menunjukkan bahwa pemahaman siswa mengenai materi yang diberikan masih rendah sehingga tidak mencapai ketuntasan klasikal yang telah ditetapkan. Umumnya siswa masih sulit 
mengubah suatu kalimat ke model matematika dan begitupun sebaliknya, serta siswa masih sulit dalam membuat tabel kebenaran. Oleh karena itu, sebelum masuk pada tahap pelaksanaan tindakan, peneliti bersama para siswa kelas IV SD 165727 Tebing Tinggi membahas soal tes awal tersebut.

Penggunaan metoed problem posing diukur dari pengamatan observer. Hasil penelitian tindakan kelas menunjukkan bahwa pengamatan yang dilakukan oleh mitra kolaborasi dan peneliti pada aktivitas guru dan siswa melalui penerapan metode problem posing pada mata pelajaran IPA di kelas IV SD Negeri 165727 Tebing Tinggi dapat dilihat pada Tabel 1 yaitu sebagai berikut:

Tabel 1. Peningkatan Hasil Belajar Siswa Pra Siklus, Siklus I dan II

\begin{tabular}{|l|l|l|l|}
\hline \multicolumn{2}{|l|}{ Peningkatan Hasil Belajar } & \multirow{2}{*}{ Keterangan } \\
\cline { 1 - 2 } $\begin{array}{l}\text { Pra } \\
\text { Siklus }\end{array}$ & $\begin{array}{l}\text { Siklus } \\
\text { I }\end{array}$ & $\begin{array}{l}\text { Siklus } \\
\text { II }\end{array}$ & Sumlah Siswa \\
\hline 75 & 26 & 30 & $\begin{array}{l}\text { Jumlus } \\
\text { Lulus }\end{array}$ \\
\hline 70,4 & 78,6 & 86 & $\begin{array}{l}\text { Persentase } \\
\text { Ketuntasan } \\
\text { Belajar (\%) }\end{array}$ \\
\hline $\begin{array}{l}\text { Tidak } \\
\text { Tuntas }\end{array}$ & $\begin{array}{l}\text { Tidak } \\
\text { Tuntas }\end{array}$ & Tuntas & $\begin{array}{l}\text { Ketajitas } \\
\text { Secara }\end{array}$ \\
\hline
\end{tabular}

$$
\text { Berdasarkan pengamatan }
$$
peneliti dari tindakan pra siklus, siklus I dan II terjadi peningkatan hasil belajar dan aktivitas siswa melalui persen ketuntasan belajar secara klasikal. Pembelajaran siklus I menggunakan metode problem posing menunjukkan adanya pe-ningkatan hasil belajar siswa. Hasil analisis data nilai keterampilan siswa mengenai materi pelaran pada tes siklus I menunjukkan bahwa persentase hasil tes siswa yang belajar tuntas naik sebesar 81,25\% dibandingkan sebelum tindakan. Siswa yang belajar tuntas secara klasikal pada siklus I sebanyak 26 siswa atau sebesar $81,25 \%$.

Berdasarkan Tabel 1 dapat dinya-takan bahwa keaktifan siswa kelas IV SDN 165727 Tebing Tinggi mengalami peningkatan da-lam setiap pelaksanaannya yakni jumlah siswa yang aktif pada pelaksanaan tindakan siklus I mencapai 78,6\%. Dengan demikian, dapat disimpulkan bahwa keaktifan siswa telah memenuhi target indikator kinerja dalam pelaksanaan tindakan kelas ini dengan menggunakan metode problem posing dalam pembelajaran IPA kelas IV SDN 165727 tahun ajaran 2015/2016.

Sebanyak 28 orang siswa setelah dilakukan tes akhir siklus I hasil belajarnya meningkat. Hanya saja peningkatan yang terjadi belum optimal karena hasil belajar masih berada dalam kategori kurang dan indeks peningkatan hasil belajar masih berada dalam kategori rendah. Meskipun demikian, terjadi 
peingkatan hasil belajar siswa dari pra siklus ke siklus I walaupun hasilnya belum sesuai dengan indikator keberhasilan. Hal ini membuktikan bahwa dengan penerapan metode problem posing dapat meningkatkan hasil belajar siswa kelas IV SD 165727 Tebing Tinggi. Pada saat kegiatan belajar siswa banyak yang suka bermain sendiri dan susah untuk diatur. Selain itu, menurut mitra kolaborasi guru dalam menyampaikan perintah atau penjelasan masih terkadang mengunakan bahasa yang susah dimengerti dan dipahami oleh siswa sehingga membuat siswa kebingungan.

Penggunaan metode Problem Posing adalah salah satu cara yang efektif untuk mengembangkan keterampilan siswa untuk meningkatkan kemampuan dalam menerapkan konsep. Hal ini sesuai dengan pendapat Kusumah (2004), pendekatan ini lebih ditekankan pada kegiatan membentuk soal yang dilakukan oleh siswa sendiri. Hal ini memberi kesempatan yang luas kepada siswa untuk mengkonstruk pengetahuan sesuai dengan perkembangan pengetahuan berfikirnya.

Pada Tabel 1, metode pembelajaran problem posing pada siklus II diperoleh ketuntasan belajar mencapai $93,75 \%$ atau ada 30 siswa dari 32 siswa sudah tuntas belajar. Hasil tersebut menunjukkan bahwa pada siklus kedua secara klasikal sudah tuntas belajar dan sudah memenuhi kriteria dari persentase ketuntasan yang dikehendaki yaitu sebesar $85 \%$. Sedangkan untuk persentase aktvitas siswa mencapai $86 \%$.

Dengan mencermati data hasil tes akhir siklus II, dapat dinyatakan bahwa terjadi peningkatan yang signifikan pada hasil belajar. Hal tersebut didukung berdasarkan jumlah siswa yang mengalami peningkatan hasil belajar. Sebanyak 30 orang siswa tuntas secara klasikal dari 32 siswa setelah dilakukan tes akhir siklus II hasil belajarnya meningkat. Siswa sudah semakin berani mengacungkan tangan terhadap hal yang belum dimengerti dan bersemangat mengkomunikasikan hasil kerja Hal ini menunjukkan bahwa pelaksanaan pembelajaran pada siklus II sudah lebih baik dari siklus I.

Dengan penerapan metode problem posing dapat meningkatkan penguasaan materi siswa untuk mata pelajaran IPA. Hal ini terlihat dari perbandingan hasil belajar siswa sebelum pemberian tindakan dengan setelah pemberian tindakan pada siklus I dan siklus II. Peningkatan yang baik dicapai setelah diberikannya tindakan dengan penerapan metode problem posing dari siklus I ke siklus II sebesar 11,6\%. Dimana dari hasil tes yang 
diberikan persentase ketuntasan siswa mencapai 93,75\%. Secara klasikal siklus II dinyatakan telah memenuhi kriteria penilaian.

Melihat kenyataan d atas, maka penerapan metode Problem Posing dalam pembelajaran Bahasa Indonesia. Walaupun masih ada anak yang mengalami berbagai kesalahan, namun secara keseluruhan dapat dikatakan mengalami peningkatan secara bertahap. Dalam metode Problem Posing, guru berperan sebagai fasilitator yang membimbing siswa melalui pertanyaan-pertanyaan yang mengarahkan siswa untuk menghubungkan pengetahuan yang lalu dengan pengetahuan yang sedang ia peroleh. Siswa didorong untuk berpikir sendiri, menganalisis sendiri, sehingga dapat menemukan konsep, prinsip, ataupun prosedur berdasarkan bahan ajar yang telah disediakan guru.

Dari hasil tes ini dapat dilihat bahwa hasil belajar dengan menggunakan metode pembelajaran problem posing telah mampu meningkatkan hasil belajar siswa mata pelajaran IPA sesuai dengan indikator yang telah ditentukan sehingga tidak perlu lagi dilanjutkan pada siklus berikutnya dan dikatakan berhasil. Berdasarkan hasil yang didapat dari setiap siklus proses pembelajaran yang optimal, hal ini ditunjukkan dengan meningkatnya penguasaan materi dan hasil belajar siswa. Oleh karena itu dapat disimpulkan bahwa proses pembelajaran dengan penerapan inkuiris angat sesuai dengan mata pelajaran Bahasa Indonesia. maka Penelitian Tindakan Kelas (PTK) ini bisa dikatakan berhasil karena hasil peningkatan proses pembelajarannya optimal.

Gambaran peningkatan ketuntasan belajar yang diperoleh setelah melakukan penelitian dengan menggunakan metode Problem Posing terlihat pada diagram berikut:

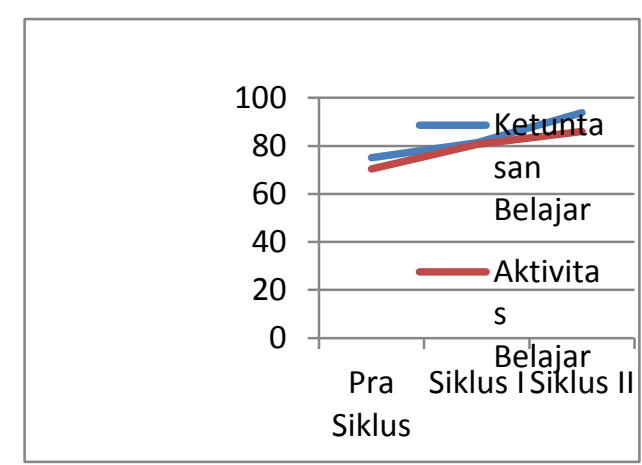

\section{Grafik 1. Peningkatan Ketuntasan Belajar}

\section{SIMPULAN}

Dari hasil temuan penelitian tentang hasil belajar siswa dengan metode problem posing di kelas IV SD Negeri 165727 Tebing Tinggi tahun pelajaran 2015/2016 diyakini mampu meningkatkan hasil belajar siswa. Hal tersebut dapat dilihat dari peningkatan persentase ketuntasan belajar siswa pada siklus I $(81,25 \%)$, siklus II $(93,75 \%)$. Sedangkan untuk 
aktivitas belajar siswa pada siklus I yaitu $80,5 \%$ dan meningkat menjadi $86 \%$ pada siklus II.

Atas dasar simpulan dan implikasi hasil penelitian tindakan kelas di atas, penulis memberikan saran-saran sebagai berikut:

1. Bagi Sekolah: fasilitas belajar seperti buku dan media pembelajaran hen-daknya lebih dilengkapi. Bagi peneliti, persiapan yang dilakukan sebelum pelaksanaan pembelajaran hendaknya lebih diperhatikan. Dengan demikian guru akan mengetahui keberhasilan dan kekurangan pembelajaran yang telah dilakukannya.

2. Bagi Guru: hendaknya bersikap lebih tegas dalam mengkondisikan siswa dan lebih giat lagi dalam memotivasi sisswa untuk aktif mengikuti pembelajaran. Selain itu, guru perlu lebih kreatif dalam merancang pembelajaran yang memberikan kesempatan kepada siswa untuk menemukan kembali pengetahuan.

3. Bagi Siswa: siswa diharapkan dapat meningkatkan aktivitas dan hasil belajar IPA siswa.sehingga siswa dapat memahami lebih cepat konsepkonsep didalam pembelajaran.

\section{DAFTAR RUJUKAN}

Dimyati dan Mudjiono. 2006. Belajar dan Pembelajaran. Jakarta: PT. Rineka Cipta.

Kusumah, Y. (2004). Model-model Pembelajaran Matematika untuk Meningkatkan Kemampuan Kognitif dan Afektif Siswa Sekolah Menengah. Disampaikan dalam Seminar Nasional Matematika yang Diselenggarakan Jurusan Pendidikan Matematika FMIPA Universitas Negeri Yogyakarta (UNY). Bandung: Jurusan Matematika FMIPA Universitas Pendidikan Indonesia.

Mahmudi, A. 2008. Pembelajaran Problem Posing Untuk Meningkatkan Pemecahan Masalah Matematika (Makalah Disampaikan Pada Seminar Nasional Matematika

Diselenggarakan Oleh Jurusan Matematika FMIPA UNPAD Bekerjasama Dengan Departemen Matematika UI Sabtu 13 Desember 2008).

Muslichah, A. 2006.P enerapan Pendekatan SainsTeknologi-Masyarakat. Jakarta: Departemen Pendidikan Nasional.

Syarifulfahmi. (2009). LangkahLangkah Pelaksanaan 
Serlitan Panjaitan: Penerapan Metode ..

Problem Posing. Diperoleh dari

http://syarifulfahmi.blogspo t.com/2009/09/pendekatanpembelajaran-problemposing.html.\%20\%2821 tanggal 30 Maret 2013.

Sanjaya, Wina. 2010. Penelitian Tindakan Kelas. Jakarta: Kencana Prenada Media Group.

Thobroni, Muhammad dan Arif. 2012. Belajar dan Pembelajaran. Yogjakarta: Ar-ruzz Media. 